\title{
Summer foraging areas for lactating New Zealand sea lions Phocarctos hookeri
}

\author{
B. Louise Chilvers ${ }^{1,4, *}$, Ian S. Wilkinson ${ }^{1,2}$, Padraig J. Duignan ${ }^{3}$, Neil J. Gemmell ${ }^{4}$ \\ ${ }^{1}$ Science and Research Unit, Department of Conservation, PO Box 10-420, Wellington, New Zealand \\ ${ }^{2} 14$ Carlisle St, Shoalwater, Western Australia 6169, Australia \\ ${ }^{3}$ New Zealand Wildlife Health Centre, IVABS, Massey University, Palmerston North, New Zealand \\ ${ }^{4}$ School of Biological Science, Canterbury University, Christchurch, New Zealand
}

\begin{abstract}
The overlap between marine mammal species and fisheries is a source of ongoing conflict and concern. This study used satellite telemetry to examine the foraging patterns of 26 lactating female New Zealand sea lions Phocarctos hookeri from the Sandy Bay colony, Enderby Island, Auckland Islands $\left(50^{\circ} 50^{\prime} \mathrm{S}, 166^{\circ} 28^{\prime} \mathrm{E}\right)$, over 4 consecutive austral summers from 2001 to 2004. Animals were fitted with satellite-linked platform transmitting terminals (PTTs), which yielded 9200 filtered foraging locations at sea. Trips lasted a mean of $66.2 \mathrm{~h}(\mathrm{SE}=4.2, \mathrm{n}=183)$. Mean return travel distance per trip was $423 \mathrm{~km}(\mathrm{SE}=43.9$, $\max .=1087, \mathrm{n}=183)$. There was a high level of variation in individual foraging parameters, and evidence of individual preference and partitioning in foraging locations among individuals within the colony. New Zealand sea lions exhibited preferential use of the continental shelf and its edge and this pattern was consistent among years. Female foraging locations overlap temporally and spatially with the operation of the sub-Antarctic arrow squid trawl fishery. Here we identify the key foraging areas for female New Zealand sea lions from Sandy Bay, show how these overlap with the operational areas of the squid fishery and discuss the importance of these findings to the management of New Zealand sea lions and the sub-Antarctic squid fishery.
\end{abstract}

KEY WORDS: Phocarctos hookeri $\cdot$ New Zealand sea lions $\cdot$ Foraging ecology $\cdot$ Fisheries interaction Resale or republication not permitted without written consent of the publisher

\section{INTRODUCTION}

Animal foraging behaviour is predicted predominantly by the abundance and distribution of their food resources (Harcourt et al. 2002). However, if there are spatial or temporal external constraints on the area that can be covered for resources (i.e. the restriction of provisioning stationary offspring), or resource competition or fluctuation, a change in foraging activity and efficiency may result in a decrease in individual and population fitness (McCafferty et al. 1998).

Such constraints are often observed for otariid seals (fur seals and sea lions), especially breeding females. Female otariids are constrained to forage near their breeding colonies as they suckle their offspring for long periods ( 4 mo to $3 \mathrm{yr}$ ) and the pup fasts while their mother is absent (Schulz \& Bowen 2004). In addition, there are many examples of otariid breeding popula- tions foraging areas that show both extensive natural fluctuations in resources, and overlap and competition with fisheries (i.e. Boyd et al. 1994, McCafferty et al. 1998, Thompson et al. 1998, Georges et al. 2000). The objective of this research was to investigate the foraging ranges of lactating female New Zealand sea lions Phocarctos hookeri (NZ sea lions, formally known as Hooker's sea lions) to (1) understand individual variation and population foraging range, (2) allow comparison of foraging ranges with the New Zealand sub-Antarctic arrow squid Nototodarus sloanii fishery operation area, (3) allow comparisons with other otariid species and (4) complement current data published on energetic and diving behaviour (Costa et al. 1998, 2001, Gales \& Mattlin 1998, Costa \& Gales 2000).

The NZ sea lion is one of the world's rarest and most highly localised pinnipeds: classified as 'Vulnerable' by the International Union for Conservation of Nature 
and Natural Resources (IUCN) (Reijnders et al. 1993) and 'Threatened' under the New Zealand Marine Mammals Protection Act 1978 (Hitchmough 2002). NZ sea lions breed on New Zealand's sub-Antarctic islands between latitudes of 48 and $53^{\circ} \mathrm{S}$ (Gales \& Mattlin 1997). Their population size is estimated at between 12000 and 15000 animals, comprising approximately 7000 adults (Gales \& Fletcher 1999, Wilkinson et al. 2003). This is one of the smallest population sizes reported for an otariid and available data suggest that this population has remained static for at least the last $27 \mathrm{yr}$, and possibly the last $40 \mathrm{yr}$ (Taylor 1971, Wilkinson et al. 2003). Ninety percent of all breeding is highly localised, occurring on Dundas and Enderby Islands within the Auckland Island group (Fig. 1).

Over the past decade, there has been considerable concern about the interaction between NZ sea lions and the arrow squid trawl fishery, which operates on the Auckland Island shelf between February and May each year (Gales 1995). The squid comprises a consistent but variable proportion of the sea lions' diet

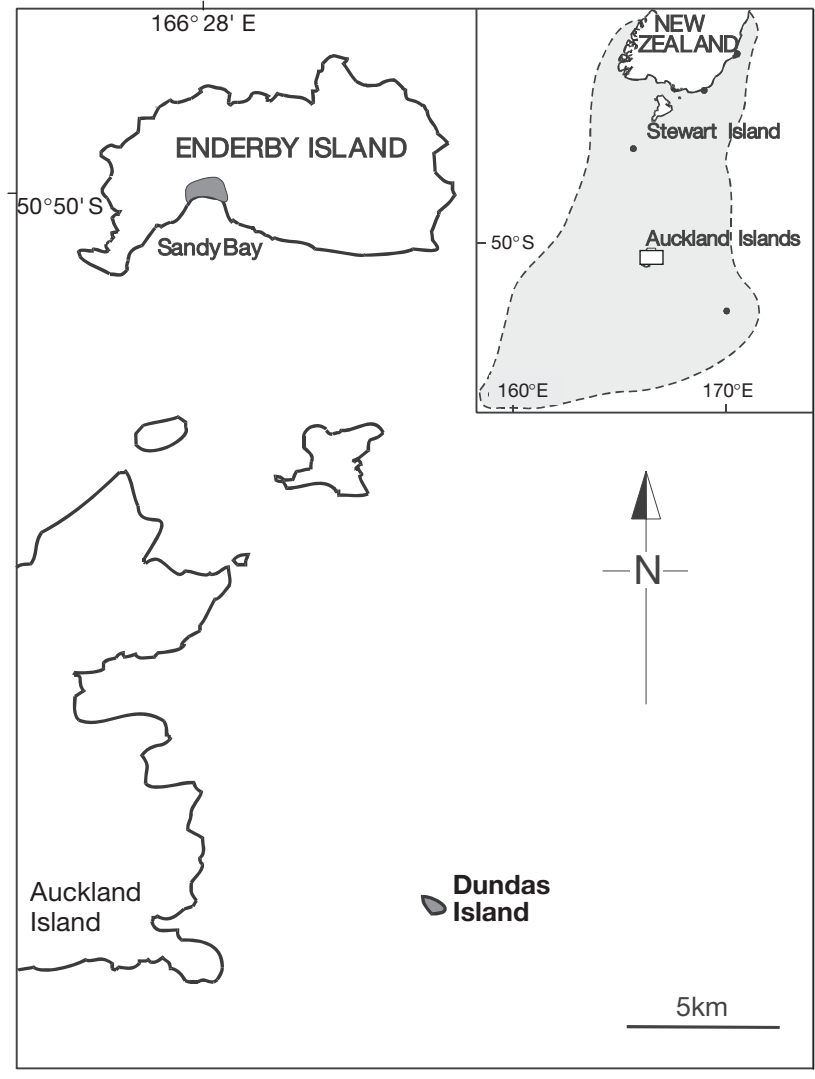

Fig. 1. Northeast Auckland Islands showing the main breeding areas for New Zealand (NZ) sea lions: Sandy Bay, Enderby Island (in grey, $50^{\circ} 50^{\prime} \mathrm{S}, 166^{\circ} 28^{\prime} \mathrm{E}$ ) and Dundas Island, $8 \mathrm{~km}$ south (in grey). Inset: New Zealand's sub-Antarctic. Grey shaded area indicates NZ sea lions' current distribution
(Childerhouse et al. 2001), and its presence around the Auckland Islands coincides with the first 4 mo of lactation for the NZ sea lions (Gales 1995). With both sea lions and trawlers targeting the same prey, accidental captures of sea lions in squid trawl nets are inevitable, and between 17 and 140 sea lion deaths are reported to occur each fishing season (Baird 1996, Wilkinson et al. 2003). The impact of fisheries-related mortality on the sea lion population is as yet unknown, but several models suggest that this level of take may limit the capacity for NZ sea lions to increase in numbers and under some scenarios result in population decline (Doonan \& Cawthorn 1984, Woodley \& Lavigne 1993). This uncertainty about impacts on the population is heightened when considering other natural regulators of population growth. Over the past $7 \mathrm{yr}$, this species has been affected by 3 epidemics caused by bacterial infection (Duignan 1999, Wilkinson et al. 2003, P. J. Duignan unpubl. data). These events resulted in the deaths of 53, 32 and $21 \%$ of the 1998, 2002 and 2003 seasons' pup production within 6 wk of the mean birth date, respectively, and of at least 75 adult females during the 1998 epidemic (Duignan 1999, Wilkinson et al. 2003, P. J. Duignan unpubl. data). These episodic events are an added stress that leaves the population susceptible to direct external impacts, such as fisheries-related mortality.

Female NZ sea lions have the deepest and longest duration dives recorded for any otariid (Gales \& Mattlin 1997). A major feature of their diving behaviour is that they dive almost continuously when at sea (Gales \& Mattlin 1997); this is thought to reflect a marginal foraging environment in which diving behaviour is close to physiological limits (Gales \& Mattlin 1997, B. L. Chilvers unpubl. data).

Diving (Gales \& Mattlin 1997) and dietary analysis (Childerhouse et al. 2001) suggest that female NZ sea lions are benthic feeders, with little evidence of midwater feeding. The distribution of dive depths suggests that lactating females forage across, and at the edges of, the Auckland Islands shelf. However, these data do not indicate the direction or distance of foraging areas from the colony (Gales \& Mattlin 1997).

In this study, we used satellite telemetry to determine the areas in which lactating female NZ sea lions forage, investigate individual variation, and identify patterns in highly utilised summer foraging areas. We then used these data to examine the relationship between female NZ sea lion foraging areas and the operations of commercial fishing, including locations of fisheries by-catch of sea lions. We also compared female NZ sea lion foraging behaviours to those of other otariids to investigate whether behaviour or physiological differences between species indicate a restriction in this population's viability. 


\section{MATERIALS AND METHODS}

This study was conducted at the Sandy Bay breeding colony, Enderby Island, Auckland Islands $\left(50^{\circ} 30^{\prime} \mathrm{S}\right.$, $166^{\circ} 17^{\prime} \mathrm{E}_{\text {; Fig. }}$ ) over the 4 breeding seasons (December to January) of 2001 to 2004. The Sandy Bay colony is the second largest breeding colony for NZ sea lions, with approximately 400 to 500 pups born per year (Gales \& Fletcher 1999). Female NZ sea lions come ashore 1 to $3 \mathrm{~d}$ before giving birth from early December to early January. Mothers give birth to a single pup and remain with it for 5 to $10 \mathrm{~d}$ before returning to sea to forage (Cawthorn et al. 1985). They then alternate between feeding trips at sea (1 to $5 \mathrm{~d}$ ) and nursing of the pup ashore ( 1 to $3 \mathrm{~d}$ ) until the pups are weaned at approximately 9 mo of age (Cawthorn et al. 1985).

Branded female NZ sea lions observed to be suckling a pup were captured using a specially designed hoop net and physically restrained by 2 handlers; they were then anaesthetised using isoflurane delivered with oxygen to a mask via a field-portable vaporiser (Gales \& Mattlin 1998), which has been routinely applied to pinnipeds and over 1000 NZ sea lions (Gales \& Mattlin 1998, Costa \& Gales 2000, I. S. Wilkinson \& P. J. Duignan unpubl. data). Satellite-linked platform transmitting terminals (PTTs) (Telonics $300 \mathrm{~mW} \mathrm{ST6}$, potted in epoxy, $130 \mathrm{~mm} \times 35 \mathrm{~mm} \times 15 \mathrm{~mm} \times 175 \mathrm{~g}$, Telonics Mesa), VHF transmitters $(70 \mathrm{~mm} \times 30 \mathrm{~mm} \times 15 \mathrm{~mm}$, Sirtrack) and time-depth recorders (TDR) (Mk9, $40 \mathrm{~mm}$ $\times 30 \mathrm{~mm} \times 22 \mathrm{~mm}$ and $65 \mathrm{~mm} \times 8 \mathrm{~mm} \times 18 \mathrm{~mm}$, Wildlife Computers) were attached to the females. Prior to deployment, each instrument was glued to a piece of neoprene material cut to the same size as the unit's base (Gales \& Mattlin 1997). This neoprene base was then glued to the dorsal pelage of the sea lion using 2part epoxy glue. When the animals were recaptured, the instruments could then be easily removed by cutting through the middle of the neoprene, and therefore not cutting into the tag or sea lion hair. Once the PTT units were adequately attached to the sea lion (8 to 10 min after glue application), the flow of anaesthetic was stopped, and the animal allowed to recover and return to its pup. Each animal was observed after restraint until it was fully conscious and had returned to the group or location where captured. All females were recaptured before the end of the field season (18 February) to retrieve instruments. Satellite tags were programmed to work continuously, but were fitted with salt-water and wet-dry switches to ensure that transmission only occurred when animals were at sea and on the surface.

Locations. Sea lion locations were calculated by reference to 3 satellites and assigned by Argos to 6 classes on the basis of their accuracy. The accuracy of locations provided by Argos is classified as follows:
(1) Class 3, accurate to $150 \mathrm{~m}_{i}$ (2) Class 2, accurate to $350 \mathrm{~m}_{i}$ (3) Class 1, accurate to $1 \mathrm{~km}_{i}(4)$ Class 0, accurate to $\geq 1 \mathrm{~km}$; and (5) Classes A and B, limited accuracy. Only the 4 most accurate classes $(0,1,2,3)$ were included in these analyses (Boyd et al. 1998, Bonadonna et al. 2000). Locations were filtered using a maximum swimming speed parameter of $2 \mathrm{~m} \mathrm{~s}^{-1}$ (Crocker et al. 2001). Locations with a running mean speed greater than this value were excluded as outliers.

Filtered locations were used to estimate distance from Enderby Island, and distance travelled. Total distance travelled resulted from the interpolation of all filtered locations. Due to the errors related to the accuracy of satellite locations, all distance calculations are presented to the nearest $1 \mathrm{~km}$. This error factor needs consideration when interpreting results. The duration of trips and periods ashore were calculated from satellite data. Calculations of mean distance travelled per trip, maximum distance from the breeding colony and kernel ranges (KRs) (Worton 1989) were restricted to complete trips (those defined by locations at the colony or within $10 \mathrm{~km}$ from the colony while the sea lions were travelling towards it). Locations from incomplete trips are represented in figures and tables but were not used in trip statistics. KRs for 50 and $65 \%$ of all locations per sea lion were created using the Animal Movement Extension of ARCVIEW (Hooge et al. 2000). KRs representing 50 and $65 \%$ of all of the locations were thought to show representative ranges of foraging locations with 2 values helping to determine the concentration of locations within foraging areas. These values were obtained using smoothing factors calculated via least-square cross-validation (Seaman \& Powell 1996) and were averaged and used to compare representative foraging area size between individuals, using 1-way ANOVAs. Weighted (by number of sightings) and un-weighted averages were both employed to determine whether there was any bias in KR sizes due to differences in the number of sightings for each individual. KR sizes (both 50 and $65 \%$ ) were plotted relative to the number of foraging trips and compared using 1-way ANOVAs.

All trip variables derived from location data were analysed using Excel, SPSS and ARCVIEW (Microsoft Office Excel 2003, ARCVIEW ${ }^{\odot} 1998$ ESRI, SPSS 2004). Individual variations in trip variables were analysed using 1-way ANOVAs or non-parametric Kruskal-Wallis tests. Pearson's correlations were used to compare the correlations between foraging variables and between female age and foraging variables. Since NZ sea lions dive almost continuously while at sea (Gales \& Mattlin 1997), all trips and satellite locations are assumed to be part of a foraging trip and to represent foraging locations. The arrow squid fisheries operational locations and sea lion bycatch data were sup- 
plied by the Research Data Management section of the Ministry of Fisheries, New Zealand. Fisheries data represent all start/stop locations for trawl shoots undertaken each year. KRs representing 50 and $95 \%$ of all trawler activity were created to show areas of highest activity. These values were calculated the same way as those for the foraging areas as outlined above.

\section{RESULTS}

\section{New Zealand sea lion foraging trip patterns}

Twenty-six females yielded 9200 filtered locations, with equipment deployed or active for between 5 and $36 \mathrm{~d}$ for each female (Table 1, Fig. 2). The per- centage of each Argos location quality category after filtering for 9200 locations was: (1) Classes 2 and 3 (8\%); (2) Class 1 (24\%); (3) Class 0 (68\%). Deployment year, female identification, number of days deployed, total number of filtered satellite locations, numbers and duration of foraging trips, and other foraging trip statistics are shown in Table 1. There were 183 complete foraging trips identified with a mean of 7 trips per individual $(\min .=1, \max .=15)$ lasting on average $66 \mathrm{~h}$ (Table 1). The mean maximum distance travelled from breeding to foraging sites was $102 \mathrm{~km}$ (range $=\sim 33$ to $188 \mathrm{~km}$, Table 1). Mean distance and time between interpolated locations were $9 \mathrm{~km}$ and $2.1 \mathrm{~h}$, respectively. Mean trip distance was $423 \mathrm{~km}$ (range $=58$ to $901 \mathrm{~km}$ ). The mean duration ashore between foraging trips was

Table 1. Phocarctos hookeri. Deployment between 2001 and 2004 (all instruments were deployed for various time periods between 12 January and 18 February within each year); number of days deployed and duration of foraging trips for 26 New Zealand sea lions from Sandy Bay breeding colony, Enderby Island, Auckland Islands, are shown. All means presented \pm SE. na $=$ not available

\begin{tabular}{|c|c|c|c|c|c|c|c|c|c|c|c|}
\hline $\begin{array}{l}\text { Female } \\
\text { ID }\end{array}$ & $\begin{array}{l}\text { Age } \\
\text { (yr) }\end{array}$ & $\begin{array}{l}\text { No. } \\
\text { days } \\
\text { de- } \\
\text { ployed }\end{array}$ & $\begin{array}{l}\text { Total } \\
\text { no. of } \\
\text { loca- } \\
\text { tions }\end{array}$ & $\begin{array}{l}\text { No. } \\
\text { of } \\
\text { trips }\end{array}$ & $\begin{array}{l}\text { Mean } \\
\text { time } \\
\text { at sea } \\
(\mathrm{h})\end{array}$ & $\begin{array}{l}\text { Mean } \\
\text { time } \\
\text { ashore } \\
(\mathrm{h})\end{array}$ & $\begin{array}{c}\text { Total } \\
\text { travel } \\
\text { distance } \\
(\mathrm{km})\end{array}$ & $\begin{array}{c}\text { Mean } \\
\text { trip } \\
\text { distance } \\
(\mathrm{km})\end{array}$ & $\begin{array}{l}\text { Max. } \\
\text { trip } \\
\text { distance } \\
(\mathrm{km})\end{array}$ & $\begin{array}{c}\text { Mean travel } \\
\text { speed between } \\
\text { satellite } \\
\text { locations }\left(\mathrm{m} \mathrm{s}^{-1}\right)\end{array}$ & $\begin{array}{c}\text { Max. } \\
\text { distance } \\
\text { from colony } \\
(\mathrm{km})\end{array}$ \\
\hline \multicolumn{12}{|l|}{2001} \\
\hline 1424 & 9 & 29 & 338 & 15 & $23.5 \pm 3.0$ & $20.6 \pm 2.7$ & 4634 & $305 \pm 32.3$ & 601 & 3.4 & 95.9 \\
\hline 1474 & 8 & 36 & 588 & 10 & $65.0 \pm 6.6$ & $20.6 \pm 3.3$ & 3710 & $358 \pm 44.4$ & 554 & 1.4 & 69.5 \\
\hline 1480 & 8 & 34 & 258 & 6 & $96.1 \pm 15.5$ & $14.3 \pm 1.5$ & 2152 & $335 \pm 42.2$ & 406 & 0.9 & 75.9 \\
\hline 1438 & 10 & 34 & 666 & 12 & $65.1 \pm 10.4$ & $15.1 \pm 1.4$ & 5000 & $401 \pm 69.9$ & 924 & 1.4 & 92.1 \\
\hline \multicolumn{12}{|l|}{2002} \\
\hline 1428 & 11 & 27 & 396 & 5 & $83.8 \pm 7.9$ & $18.9 \pm 1.4$ & 3560 & $693 \pm 64.4$ & 871 & 2.0 & 145.5 \\
\hline 1500 & 10 & 26 & 230 & 5 & $90.2 \pm 5.1$ & $16.6 \pm 2.2$ & 3567 & $697 \pm 104.6$ & 895 & 1.8 & 188.0 \\
\hline 1375 & 12 & 17 & 308 & 4 & $70.3 \pm 12.9$ & $27.8 \pm 6.5$ & 2898 & $710 \pm 103.5$ & 1004 & 2.3 & 85.1 \\
\hline 1422 & $-^{\mathrm{a}}$ & 12 & 122 & 7 & $20.9 \pm 5.6$ & $26.2 \pm 4.2$ & 983 & $128 \pm 65.1$ & 251 & 1.7 & 52.3 \\
\hline 1413 & 12 & 28 & 666 & 7 & $80.4 \pm 5.8$ & $14.1 \pm 2.7$ & 5012 & $672 \pm 86.0$ & 975 & 1.7 & 87.5 \\
\hline 1423 & 10 & 31 & 366 & 8 & $66.1 \pm 7.6$ & $15.7 \pm 3.1$ & 2988 & $316 \pm 52.8$ & 586 & 1.1 & 85.9 \\
\hline \multicolumn{12}{|l|}{2003} \\
\hline 1433 & 12 & 33 & 351 & 6 & $79.6 \pm 5.7$ & $29.1 \pm 5.3$ & 1985 & $309 \pm 29.4$ & 407 & 1.1 & 118.8 \\
\hline 1391 & 10 & 31 & 328 & 10 & $43.8 \pm 5.6$ & $20.3 \pm 1.3$ & 3461 & $323 \pm 47.8$ & 526 & 1.9 & 86.4 \\
\hline 1397 & 11 & 30 & 463 & 6 & $96.4 \pm 14.8$ & $36.8 \pm 3.1$ & 3601 & $696 \pm 85.5$ & 976 & 1.8 & 162.5 \\
\hline 1492 & 12 & 8 & 86 & 2 & $65 \pm 2.9$ & $41.6 \pm$ na & 399 & $185 \pm 3.9$ & 189 & 0.7 & 58.4 \\
\hline 1458 & 12 & 32 & 476 & 6 & $95.6 \pm 9.5$ & $23.9 \pm 5.0$ & 2918 & $435 \pm 70.9$ & 764 & 1.0 & 154.8 \\
\hline 1409 & 12 & 31 & 776 & 8 & $67.4 \pm 5.7$ & $20.1 \pm 2.2$ & 3279 & $344 \pm 51.3$ & 563 & 1.0 & 74.9 \\
\hline \multicolumn{12}{|l|}{2004} \\
\hline 1483 & 10 & 30 & 72 & 7 & $48.7 \pm 9.0$ & $41.4 \pm 2.1$ & 546 & $58 \pm 12.7$ & 125 & 0.4 & 32.6 \\
\hline 1406 & 15 & 5 & 66 & 1 & 126.9 & na & 509 & na & 508 & 0.9 & 69.6 \\
\hline 1485 & 14 & 31 & 115 & 6 & $60.5 \pm 4.8$ & $32.2 \pm 4.4$ & 1141 & $169 \pm 23.8$ & 279 & 0.7 & 69.2 \\
\hline 1385 & 17 & 28 & 91 & 4 & $83.7 \pm 12.1$ & $44.4 \pm 1.6$ & 1448 & $291 \pm 18.8$ & 342 & 0.7 & 134.5 \\
\hline 1470 & 15 & 33 & 657 & 7 & $82.0 \pm 7.3$ & $30.1 \pm 3.0$ & 7681 & $901 \pm 43.4$ & 1087 & 2.3 & 110.2 \\
\hline 1484 & 13 & 32 & 239 & 4 & $68.6 \pm 15.9$ & $34.7 \pm 9.4$ & 2251 & $427 \pm 22.8$ & 492 & 1.7 & 94.4 \\
\hline 1443 & 12 & 31 & 260 & 8 & $45.5 \pm 5.4$ & $32.2 \pm 2.9$ & 2219 & $220 \pm 41.4$ & 439 & 1.1 & 162.7 \\
\hline 1439 & 10 & 33 & 398 & 8 & $53.8 \pm 3.0$ & $33.3 \pm 3.8$ & 3977 & $489 \pm 40.8$ & 616 & 2.0 & 91.1 \\
\hline 1456 & 13 & 33 & 374 & 14 & $35.4 \pm 3.5$ & $23.8 \pm 1.9$ & 5973 & $415 \pm 39.4$ & 626 & 3.4 & 145.9 \\
\hline 1462 & 15 & 31 & 510 & 7 & $67.2 \pm 4.3$ & $36.4 \pm 3.3$ & 5662 & $724 \pm 94.1$ & 1038 & 2.8 & 130.7 \\
\hline $\begin{array}{l}\text { Overall } \\
\text { means }\end{array}$ & & $28 \pm 1.6$ & $353 \pm 40.1$ & $7 \pm 0.6$ & $66.2 \pm 4.2$ & $26.8 \pm 1.8$ & $3127 \pm 359.5$ & $423 \pm 43.9$ & $617 \pm 55.1$ & $1.6 \pm 0.2$ & $102 \pm 7.7$ \\
\hline
\end{tabular}




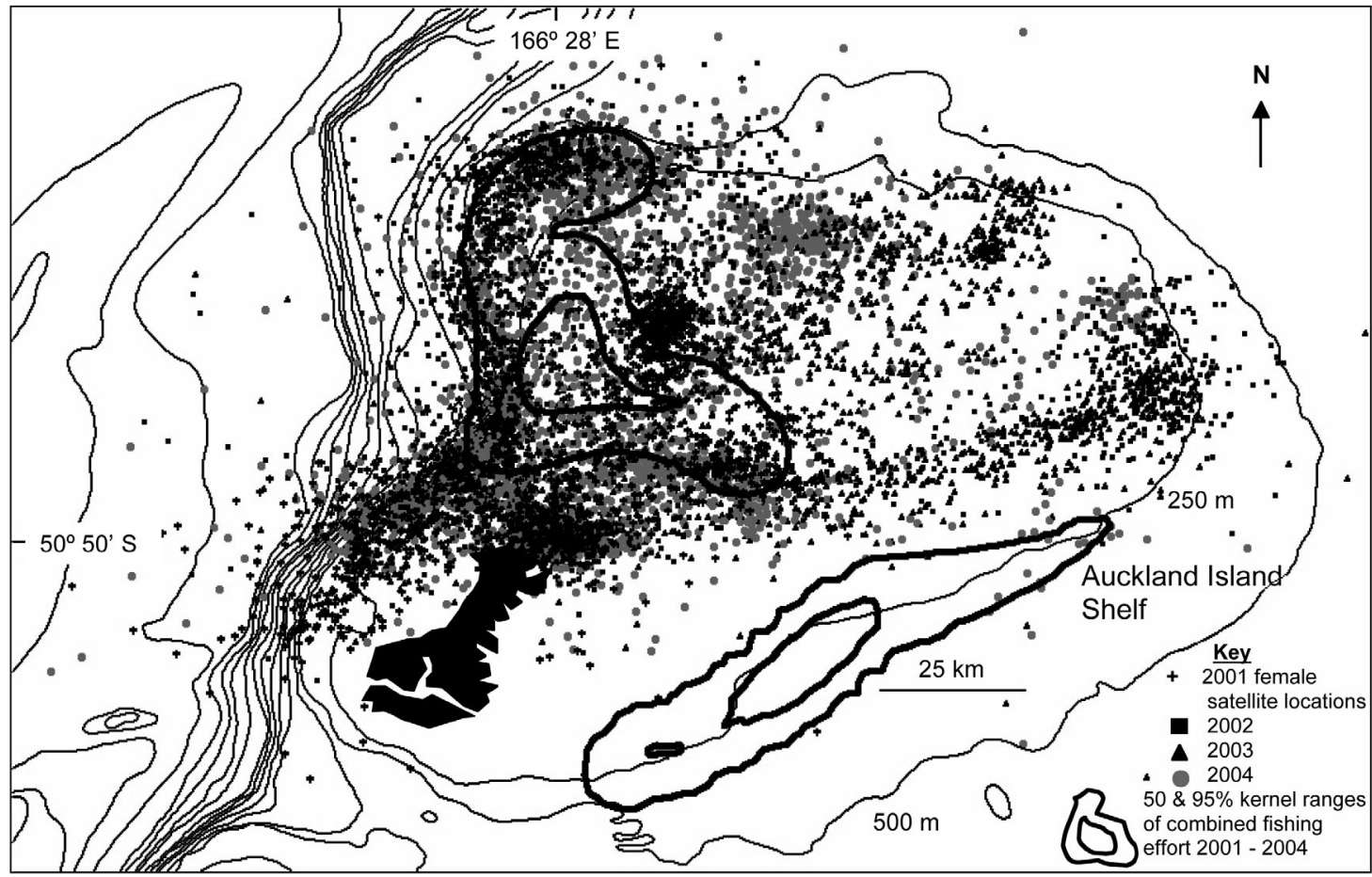

Fig. 2. Phocarctos hookeri. Distribution of foraging locations of 26 lactating NZ female sea lions and overlap with squid trawl fisheries effort (50 and 95\% kernel ranges represented as thick black lines) from the austral summers of 2001 to 2004 . Auckland Island is represented in black. Bathymetric contours are shown as thin black lines. Auckland Island shelf is represented by $500 \mathrm{~m}$ bathymetric boundary

$26.8 \mathrm{~h}$ (range $=\sim 14$ to $44 \mathrm{~h}$ ). There was no correlation between the length of time individuals spent ashore and the distance or duration of the preceding or subsequent foraging trip.

There was a significant positive correlation between the distance travelled on a trip and its duration, with longer trips having longer durations (Pearson's $r=$ $0.567, \mathrm{n}=182, \mathrm{p}<0.01$, Table 1 ). There was also a significant positive correlation between trip distance and mean travel speed between satellite locations, with longer trips having significantly higher travel speeds (Pearson's $r=0.441, \mathrm{n}=182, \mathrm{p}<0.01$ ). There was a significant negative correlation between travel speed and trip duration, with the longer the duration of the foraging trip, the slower the mean travel speed (Pearson's $r=-0.353, \mathrm{n}=182, \mathrm{p}<0.01)$; therefore, females used a combination of travel speed and prolonged foraging trip durations to cover longer distances. Mean travel speed between locations for all females was $1.6 \pm$ $0.2 \mathrm{~m} \mathrm{~s}^{-1}$, with individual differences ranging from 0.7 to $3.4 \mathrm{~m} \mathrm{~s}^{-1}$ (Table 1).

Examination of the tracks of foraging trips of the female NZ sea lions showed that they predominantly moved north from Enderby Island and that these trip directions were constant between foraging trips for most females (Fig. 3). In all years, the principal forag- ing areas were both northeast and northwest of Enderby Island at the continental shelf margins, and within the limits of the Auckland Rise (Fig. 2). Individual NZ sea lion direction of foraging showed significant individual variation between females (KruskalWallis $\chi^{2}=177.17$, df $=25, \mathrm{p}<0.0001$, Fig. 3). The variation in the foraging trip direction taken by each female was usually small, with 20 of the 26 females having a foraging direction range less than $20^{\circ}$ (i.e. her foraging trips would range at angles between 4 and $24^{\circ}$ from Enderby Island). The largest variation was $62^{\circ}(\mathrm{n}=14)$ and the smallest $6^{\circ}(\mathrm{n}=6)$. There are 3 distinct concentrations or patterns of female foraging locations: (1) west and southwest of the Enderby/ Auckland Islands area, mean distance to KR from Enderby being 30 to $50 \mathrm{~km}$ and representing 5 of the 26 females and $15 \%$ of all satellite locations within an approximate $1000 \mathrm{~km}^{2}$ area; (2) northeast of Enderby Island, mean distance to KR from Enderby being 50 to $100 \mathrm{~km}$ and representing 11 of the 26 females over a dispersed area; and (3) the area directly north and west of Enderby and Auckland Islands, and northwest of these islands surrounding the $250 \mathrm{~m}$ bathymetric line, where 9 of the 26 females and $18 \%$ of all satellite locations are concentrated within an approximately $2000 \mathrm{~km}^{2}$ area. 

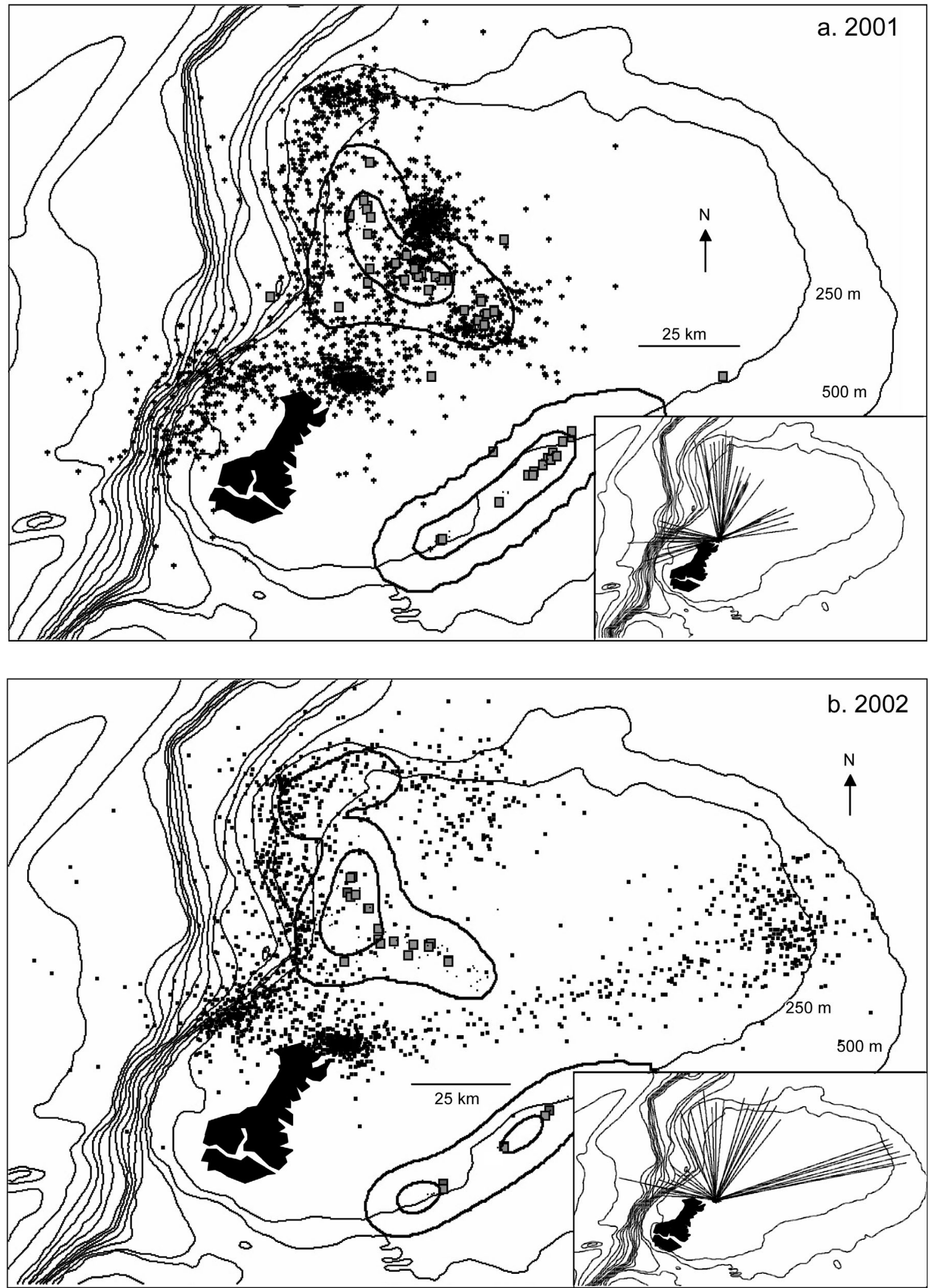

Fig. 3. (Above and facing page.) Phocarctos hookeri. All filtered satellite locations from female NZ sea lions during January and February of the austral summers 2001 to 2004; all sea lion bycatches reported in each year (large grey squares) and the squid trawl fisheries effort for February and March of each year shown as 50 and $95 \%$ kernel ranges (thick black lines). Bathymetric contours are shown as thin black lines. Insets: direction and maximum distance from pupping site of foraging trips obtained from satellit locations and tracks for NZ sea lions from Sandy Bay in each year. See Fig. 2 for key to symbols 

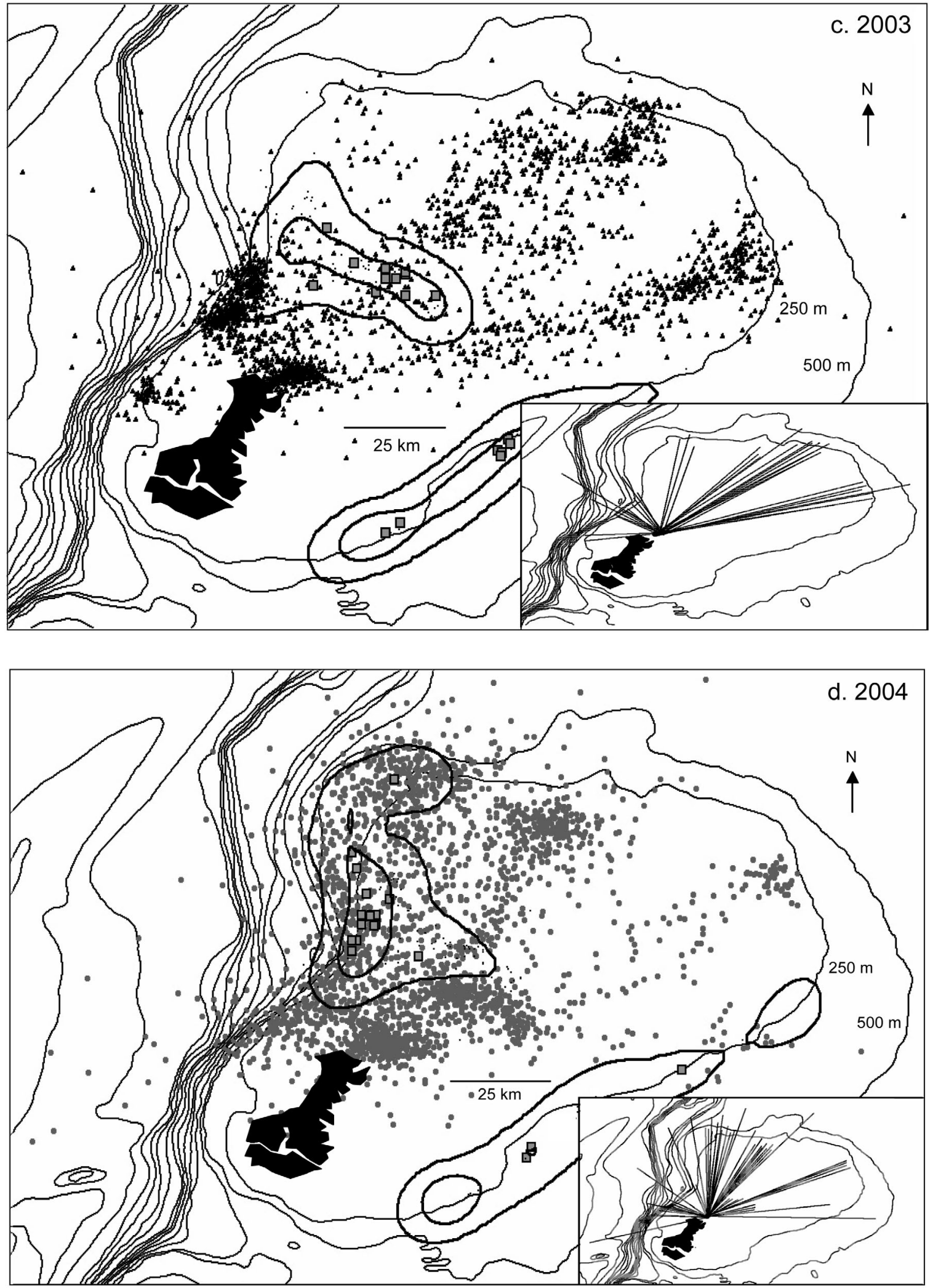

Fig. 3 (continued) 


\section{Individual variation}

Individual attendance and foraging duration patterns showed considerable variation, with trip durations ranging from 20 to $126 \mathrm{~h}$ and attendance patterns varying from 14 to $44 \mathrm{~h}$ (1-way ANOVA: attendance $F=7.2, \mathrm{p}<0.001, \mathrm{df}=25$; trip duration $F=8.9, \mathrm{p}<$ 0.001 , df $=25$; Table 1 ). There was no correlation between the duration a female spent ashore and the duration of her previous or subsequent foraging trip.

Similarly, there were significant differences between individuals in the mean distances travelled for each foraging trip (range $=58$ to $901 \mathrm{~km}, 1$-way ANOVA: $F=$ 12.6, $\mathrm{p}<0.001, \mathrm{df}=25)$ and the mean travel speed between satellite locations for each individual (travel speed $F=14.1, \mathrm{p}<0.001, \mathrm{df}=25$ ). The mean distance individuals travelled and the duration of their trips, trip distance and travel speed were positively correlated, while a negative correlation existed between travel speed and trip duration (see 'New Zealand sea lion foraging trip patterns' section).

KR was calculated for 50 and $65 \%$ of all locations for each lactating female to give an indication of the areas in which females concentrated their foraging activity (Table 2). There were high levels of variability and significant differences in the sizes of the KR between individuals with mean areas of $378 \pm 80.5 \mathrm{~km}^{2}$ for $50 \% \mathrm{KR}$ and $643 \pm 131.1 \mathrm{~km}^{2}$ for $65 \%$ KR (1-way ANOVA: unweighted $F=8.1, \mathrm{df}=25, \mathrm{p}<0.0001$; weighted by number of sightings $F=5420, \mathrm{df}=25, \mathrm{p}<0.0001$ ). Some females showed concentrated use of foraging areas (n $=14,50 \% \mathrm{KR}<200 \mathrm{~km}^{2}$; Table 2), while other females had diverse foraging areas, apparently not returning to the same locations each foraging trip $(\mathrm{n}=$ $6,50 \% \mathrm{KR}>500 \mathrm{~km}^{2}$, max. $=1810 \mathrm{~km}^{2} ;$ Table 2). There was no significant difference between $\mathrm{KR}$ and the number of complete foraging trips observed for each individual (1-way ANOVA: $50 \% \mathrm{KR}, F=1.68, \mathrm{df}=10$, $\mathrm{p}=0.18 ; 65 \% \mathrm{KR}, F=1.99, \mathrm{df}=10, \mathrm{p}=0.11$ ), indicating that KR is not a function of the number of foraging trips and that KR areas represent a clear fidelity to foraging areas. There was a significant difference in KR with age, with $12,13,15$ and 17 yr olds $(n=13)$ having a significantly smaller KR than the other age classes (1-way ANOVA: $F=2.7, \mathrm{df}=8, \mathrm{p}=0.016$ ). However, the only $14 \mathrm{yr}$ old female had one of the largest KR of any female (Table 2). A central point was taken from within each of these KRs and mean direct line distance to the breeding colony calculated, indicating mean direct line distance to the central foraging area for each female (Table 2). The mean distance females were foraging from the colony was $64 \pm 6.5 \mathrm{~km}(\mathrm{n}=26)$. Five females travelled an average of $>100 \mathrm{~km}$ to reach their foraging areas, while for 10 females, the mean distance to the foraging location was $\leq 35 \mathrm{~km}$.
Table 2. Phocarctos hookeri. Kernel range (KR) sizes and mean straight line distances from colony to centre of KR for 26 New Zealand sea lions from Sandy Bay breeding colony, Enderby Island, Auckland Islands. All means \pm SE

\begin{tabular}{|c|c|c|c|c|c|c|}
\hline $\begin{array}{l}\text { Female } \\
\text { ID }\end{array}$ & $\begin{array}{l}\text { Age } \\
(\mathrm{yr}) \\
1\end{array}$ & $\begin{array}{l}\text { Total } \\
\text { no. of } \\
\text { locations }\end{array}$ & $\begin{array}{l}\text { No. } \\
\text { of } \\
\text { trips }\end{array}$ & $\begin{array}{l}50 \% \\
\mathrm{KR} \\
\left(\mathrm{km}^{2}\right)\end{array}$ & $\begin{array}{c}65 \% \\
\mathrm{KR} \\
\left(\mathrm{km}^{2}\right)\end{array}$ & $\begin{array}{c}\text { Mean } \\
\text { distance } \\
\text { from colony } \\
\text { to centre } \\
\text { of } \mathrm{KR}(\mathrm{km})^{\mathrm{b}}\end{array}$ \\
\hline 1424 & 9 & 338 & 15 & 534 & 883 & 31 \\
\hline 1474 & 8 & 588 & 10 & 436 & 795 & 53 \\
\hline 1480 & 8 & 258 & 6 & 241 & 419 & 35 \\
\hline 1438 & 10 & 666 & 12 & 186 & 351 & 91 \\
\hline 1428 & 11 & 396 & 5 & 689 & 1093 & 113 \\
\hline 1500 & 10 & 230 & 5 & 875 & 1893 & 100 \\
\hline 1375 & 12 & 308 & 4 & 152 & 238 & 28 \\
\hline 1422 & $-^{\mathrm{a}}$ & 122 & 7 & 763 & 1222 & 25 \\
\hline 1413 & 12 & 666 & 7 & 398 & 504 & 59 \\
\hline 1423 & 10 & 366 & 8 & 86 & 143 & 84 \\
\hline 1433 & 12 & 351 & 6 & 89 & 264 & 115 \\
\hline 1391 & 10 & 328 & 10 & 1810 & 2786 & 63 \\
\hline 1397 & 11 & 463 & 6 & 311 & 556 & 103 \\
\hline 1492 & 12 & 86 & 2 & 64 & 95 & 35 \\
\hline 1458 & 12 & 476 & 6 & 441 & 903 & 82 \\
\hline 1409 & 12 & 776 & 8 & 140 & 270 & 27 \\
\hline 1483 & 10 & 72 & 7 & 362 & 457 & 32 \\
\hline 1406 & 15 & 66 & 1 & 42 & 70 & 37 \\
\hline 1485 & 14 & 115 & 6 & 1214 & 1959 & 62 \\
\hline 1385 & 17 & 91 & 4 & 76 & 115 & 117 \\
\hline 1470 & 15 & 657 & 7 & 187 & 253 & 103 \\
\hline 1484 & 13 & 239 & 4 & 188 & 345 & 31 \\
\hline 1443 & 12 & 260 & 8 & 131 & 194 & 26 \\
\hline 1439 & 10 & 398 & 8 & 124 & 345 & 90 \\
\hline 1456 & 13 & 374 & 14 & 159 & 232 & 29 \\
\hline 1462 & 15 & 510 & 7 & 149 & 346 & 90 \\
\hline \multicolumn{4}{|c|}{ Overall means } & $\begin{array}{c}378 \pm \\
80.5\end{array}$ & $\begin{array}{l}643 \pm \\
131.1\end{array}$ & $\begin{array}{c}63.9 \pm \\
6.5\end{array}$ \\
\hline \multicolumn{7}{|c|}{$\begin{array}{l}\text { a Age unknown } \\
\text { bMean straight line distance from KR to colony taken from } \\
\text { the middle of both the KRs as they are both centred on } \\
\text { the same area }\end{array}$} \\
\hline
\end{tabular}

Female age was strongly correlated with mean duration ashore and the mean foraging trip distance. Older females had significantly longer foraging trip distances and significantly longer periods ashore between foraging trips (duration ashore: Pearson's $r=0.463, \mathrm{n}=174$, $\mathrm{p}<0.001$; mean trip distance: Pearson's $r=0.278, \mathrm{n}=$ 174, p < 0.001). There was also a weak correlation between female age and duration of foraging trip, with older females having longer foraging trip durations than younger females (Pearson's $r=0.175, \mathrm{n}=174, \mathrm{p}=$ 0.02). There was no correlation between mass and any foraging trip parameters; however, mass was significantly correlated with age, with older females being heavier (mass range $=89$ to $133 \mathrm{~kg}$, 1-way ANOVA: $F=37.1, \mathrm{df}=8, \mathrm{p}<0.001)$. 


\section{Bathymetry}

Considering all satellite locations, 92.2, 77.8 and $14.4 \%$ were recorded in water of $<500,<250$ and 250 to $500 \mathrm{~m}$ water depth, respectively. The mean water depth recorded for all locations was $370.5 \pm 3.8 \mathrm{~m}$ (mode $=250 \mathrm{~m}, \mathrm{n}=9200$ ). Individual females showed apparent preferences for particular mean water depths (Kruskal-Wallis $\chi^{2}=1968.8$, df $=25, \mathrm{p}<0.0001$ ). Twelve females were rarely recorded in water deeper than $250 \mathrm{~m}$, while 1 female (ID \#1424) had a mean water depth from satellite location of $815 \pm 49.6 \mathrm{~m}$ because 48 out of 338 of her locations were recorded in water deeper than $2000 \mathrm{~m}$.

\section{Fisheries interactions}

There is extensive overlap in NZ sea lion foraging locations and fisheries operations area. Fig. 3 shows female sea lion trip patterns, satellite locations, the KR areas of $95 \%$ of all squid fishery trawl operation and the locations of sea lion captures on boats with observers for each year. The age of sea lions captured in the fisheries were all recorded as adult sea lions between the ages of 3 and $18 \mathrm{yr}$. The sex ratio for sea lion bycatch that were sexed ranged between $60 \%$ female and $40 \%$ male in 2001 to $78 \%$ female and $22 \%$ male in 2004. These values are not exact as not all sea lions were sexed and some animals are known to have been sexed wrongly (P. J. Duignan unpubl. data). Over the last $10 \mathrm{yr}$, the sex ratio of bycaught animals has been approximately 50/50\% (P. J. Duignan unpubl. data). Although the number of trawls undertaken by the fishery varies between years, their locations are similar (Fig. 3). Two fishing areas predominate: one lies southeast of the Auckland Islands along the $250 \mathrm{~m}$ bathymetry line ( $44 \%$ of all tows undertaken in the last $4 \mathrm{yr})$; the second north/northwest of the Auckland Islands (56\% of all tows undertaken in the last $4 \mathrm{yr}$ ). There is little overlap between the foraging locations of females from Enderby Island and the fishing area southeast of the Auckland Islands (Fig. 3). This fishing area represents $28 \%$ of all sea lion captures in the last $4 \mathrm{yr}$, and equates to approximately $44 \%$ of all tows undertaken and $39 \%$ of total catch by weight.

Of the 3 predominant female foraging location patterns, the first 2 (west and southwest of the Enderby/ Auckland Islands and northeast of Enderby Island) have little overlap with fisheries operations (Fig. 3). However, the third, directly north and west of Enderby and the Auckland Islands, and northwest along the $250 \mathrm{~m}$ bathometric line, has significant overlap with fisheries operations. Here, 9 of the 26 females and $18 \%$ of all satellite locations were concentrated within a
$2000 \mathrm{~km}^{2}$ area. In this same area, $56 \%$ of all trawl activity was recorded, resulting in $61 \%$ of total catch by weight in the last 4 yr. However, it is also the area in which $72 \%$ of all fisheries bycatch captures of sea lions have been reported. The reporting of bycatch is dependent on observers and fisheries reporting its occurrence. This reporting system may cause bias in data if either observer coverage varies significantly between the 2 fishing areas and/or fisheries neglect to report captures.

\section{DISCUSSION}

Our study demonstrates individual variation and preferences in foraging areas among lactating NZ sea lions. It also shows the consistency in the diversity of locations utilised across years; individual females consistently returning to relatively restricted foraging areas and travel direction each foraging trip (mean $50 \% \mathrm{KR}=378 \pm 80.5 \mathrm{~km}^{2}$, mean $65 \% \mathrm{KR}=643 \pm$ $131.1 \mathrm{~km}^{2}$ ). KR areas were not a function of the number of foraging trips studied and indicate a high site fidelity to specific foraging areas for most females. KR analysis assumes equal probability of obtaining a location at any given time. For marine mammals, this assumption can sometimes be incorrect due to different behaviours (such as grooming, submerged travelling and dive bouts) influencing the probability of a good quality uplink to the receiver. However, when determining foraging locations for benthic foragers, such as NZ sea lions, this problem is lessened because there is a relatively long interval between benthic dives, during which animals are resting on the surface. This assumption is also supported from additional concurrent dive data collected for some of these females using time depth recorders (TDRs), which show diving concentrated in areas of high satellite uplinks (B. L. Chilvers unpubl. data).

Lactating NZ sea lions from the Enderby Island breeding colony are central place foragers (Boyd et al. 1997, 1998), principally foraging in areas north of the colony and returning to the colony to transfer resources to their pups. Most locations were within the limits and at the edges of the Auckland Rise (Fig. 2). Lactating female Antarctic, New Zealand and Australian fur seals Arctocephalus gazella, A. forsteri and A. pusillus doriferus, respectively; and Australian and California sea lions Neophoca cinerea and Zalophus californianus, respectively, also forage over continental shelves or in relation to the edge of the shelves, close to breeding sites (Harcourt et al. 1995, Gales \& Costa 1997, Boyd et al. 1998, Arnould \& Hindell 2001). The geographic preference for foraging in shallower shelf waters and at shelf edges displayed by otariids 
usually results in foraging occurring within $100 \mathrm{~km}$ of breeding sites (A. gazella, Boyd et al. 2002, Guinet et al. 2001; South American sea lions Otaria flavescens, Campagna et al. 2001, Thompson et al. 1998; A. forsteri, Harcourt et al. 1995, 2002; sub-Antarctic fur seal, A. tropicalis, Georges et al. 2000; A. pusillus doriferus, Arnould \& Hindell 2001). NZ sea lion foraging location distances are within (some being at the upper end of) these observed otariid foraging limits, with mean distance to KR foraging areas of between 24 and $116 \mathrm{~km}$ from their breeding site (mean $64 \pm 6.5 \mathrm{~km}$ ), and maximum foraging locations ranging between 32 and $188 \mathrm{~km}$ (mean $102 \pm 7.7 \mathrm{~km}$; Table 1). The NZ sea lion's total foraging distances are, however, high (423 \pm $43.9 \mathrm{~km}$, present study; and $321.4 \pm 59.7 \mathrm{~km}$, Costa \& Gales 2000) relative to other otariids. For comparison, O. flavescens make foraging trips of $206 \pm 117 \mathrm{~km}$, yet have similar maximum foraging site to colony distances $($ mean $=103 \mathrm{~km}$, Campagna et al. 2001). This suggests that female NZ sea lions are covering a greater area and distance in a single foraging trip than other otariids, which may indicate high prey heterogeneity, patchiness and/or low prey abundance.

The mean travelling speed $\left(1.6 \pm 0.2 \mathrm{~m} \mathrm{~s}^{-1}\right)$ recorded here is similar to the surface swim velocity of NZ sea lions previously reported $\left(1.2 \mathrm{~m} \mathrm{~s}^{-1}\right.$, Ponganis et al. 1990; and 0.9 to $1.8 \mathrm{~m} \mathrm{~s}^{-1}$, Crocker et al. 2001). However, this value must be interpreted with caution as it was calculated from travelling speeds that were filtered to be no greater than $2 \mathrm{~m} \mathrm{~s}^{-1}$. The majority of otariid swim speeds fall within a range of 0.7 to $2.7 \mathrm{~m} \mathrm{~s}^{-1}$ (Arctocephalus gazella, Boyd et al. 2002; Otaria flavescens, Thompson et al. 1998, Campagna et al. 2001; Arctocephalus tropicalis, Georges et al. 2000). This suggests that NZ sea lions are restricted by physiological constraints for travelling speed similar to most other otariids. This is important as it limits (constrains) the distance females can travel in a given time period and influences energy returns for foraging trips (Crocker et al. 2001).

\section{Individual variation in foraging patterns}

To understand the foraging behaviours of a population, the differences in the behaviours of individuals must first be recognised (Sutherland 1997). We found significant individual differences in foraging trip duration, time ashore, distance travelled, foraging location, water depth at satellite location and maximum distance from breeding colony for NZ sea lions.

Gales \& Mattlin (1997) showed similar individual differences in NZ sea lion diving behaviours, and in an animal's preference for different foraging depths and trip durations. Similar individual variation was also observed in Arctocephalus gazella (Boyd 1999, Staniland \& Boyd 2003, Staniland et al. 2004). Such individual strategies may reflect long- or short-term learnt foraging behaviours, such as the most recently found food, learnt foraging locations from maternal transfer, or learning from con-specifics. Although we found there is a significant relationship between bathymetry and foraging location, we suggest that bathymetry is a proximate cause of the observed foraging locations, while the ultimate cause of the observed locations will be the distribution of food.

The relationship between age (and by correlation, higher mass at deployment) and foraging location, including KR values, suggests that older sea lions swam further and stayed at sea longer, but foraged in a more concentrated area than younger animals. However, they also spent greater time periods ashore between foraging trips. From a management perspective, individual foraging strategies of female NZ sea lions need to be related to their long-term reproductive success and survival to understand how foraging parameters, an indication of prey availability and distribution, are influencing population stability and viability.

\section{Fisheries interactions}

Data on squid presence in sea lion diet (Childerhouse et al. 2001), the overlapping locations of sea lion foraging areas with fisheries operations (Wilkinson et al. 2003, present study), and the fact that NZ sea lions are caught in fishing operations (Fig. 3), all indicate that the squid trawl fishery has considerable potential to impact negatively upon NZ sea lions. This study shows that the summer foraging ranges of lactating NZ sea lions from the Enderby Island colony are predominantly north of the island.

Of the 3 distinct female foraging location patterns, those that forage predominantly southwest or northeast of the Enderby/Auckland Islands have a low overlap with current fisheries operations and there is no bycatch of sea lions reported in these areas. The third concentration directly west of Enderby and Auckland Islands, and northwest of these islands surrounding the $250 \mathrm{~m}$ bathymetric line has significant overlap, and $72 \%$ of fisheries sea lion bycatch captures in the last 4 yr. There maybe possible bycatch data bias between the 2 identified fishing areas depending on observer coverage and fisheries reporting of bycatch.

There is currently a $12 \mathrm{n}$ mile $(22 \mathrm{~km})$ marine reserve surrounding the Auckland Islands group in which all fishing is banned. Although this area contains 33\% of all satellite locations from this study, it does not provide protection for the entire foraging area for any of the females tracked. If the current marine reserve were 
to be extended out to $50 \mathrm{~km}$, 8 of the 26 (31\%) females' foraging locations as observed within this study would be entirely protected. However, it would require a reserve extending to more than $100 \mathrm{~km}$ around the Auckland Islands to fully protect all of the foraging ranges of these females from Enderby Island. An alternative approach would be to restrict fishing operations in the areas to the west and northwest of the Auckland Island group. Given the observed foraging areas seen in this study, restriction of fishing effort in this area would result in the most significant decrease in sea lion bycatch and reduce fishing operations less than if a $100 \mathrm{~km}$ closed area were utilised as a conservation measure.

An interesting anomaly that the current research has identified is that approximately $28 \%$ of sea lions caught in the squid fisheries in the last $4 \mathrm{yr}$ were caught southeast of the Auckland Island group, an area in which Enderby Island breeding females do not appear to forage. This suggests that the animals being caught there are males, or females from other colonies, such as Dundas and Figure of Eight Islands. Depending on where the animals from these colonies are foraging, it may also indicate that the Enderby Island females are being disproportionately impacted upon from fisheries, with $72 \%$ of bycatch coming from areas where they may forage exclusively.

\section{CONCLUSIONS}

Our study has concentrated on the distribution of adult lactating females because of their importance to the dynamics and recovery of the species. As observed in several other otariids, we found that NZ sea lions are limited in their use of foraging locations during lactation. The spatial and temporal restriction of having to return to the same location at the end of each foraging trip to their dependant offspring and the apparent preference for within-shelf and shelf edge foraging locations restrict the distance and locations over which these animals can forage.

In combination with the diving data suggesting that NZ sea lions in the Auckland Island area may be operating at their physiological limits (Gales \& Mattlin 1997, Costa et al. 1998, Costa \& Gales 2000), we have shown that maximum female foraging trip distances and areas for NZ sea lions are greater than those recorded for the other 4 extant sea lion species. We therefore conclude and concur with Gales \& Mattlin's (1997) suggestion that this area represents a marginal foraging environment in which diving and foraging behaviours are close to the females' and their pups' physiological limits. These conditions may have prevented population growth at this site.
Female locations at sea overlap with the operational areas and depths of the trawling fleet (Gales \& Mattlin 1997, Uozumi 1998, Wilkinson et al. 2003, present study). The reported broad-spectrum diet of NZ sea lions (Childerhouse et al. 2001) may buffer or delay the effects of an overlap with fisheries, with this currently being seen in the form of a static population with no growth. However, it is predicted that changes in the distribution and availability of preferred prey in relation to colony location will affect foraging effort of central place foragers such as NZ sea lions (Boyd et al. 1997, 1998). In particular, a sub-optimal foraging condition for a mother attempting to optimize the return time to the pup will increase foraging costs, hinder pup provisioning and affect species viability (Boyd et al. 1997, 1998). The overlap in NZ sea lion foraging locations and fisheries operations also indicates the potential for ecological resource competition between the squid fishing fleet and the sea lion population (Wilkinson et al. 2003, present study). Results of such competition may already be evident, with the mean weights of 1 mo old pups born at Sandy Bay showing an overall decline in the last $5 \mathrm{yr}$, particularly in males (I. S. Wilkinson pers. comm.). In addition, NZ sea lion milk fat content during early lactation is the lowest recorded for an otariid and shows high yearly variability with an overall trend of decline in the last 5 yr (F. Riet Sapriza pers. comm.). It is possible that fishing activity for squid in regions of the highest sea lion activity, northwest of Enderby Island, could impact food availability for sea lions during lactation. The fishing season is concentrated over only a short time period, February to May, which coincides with the first 4 mo of a 9 mo lactation period, when the pups are growing most rapidly and are totally dependent on maternal provisioning (B. L. Chilvers unpubl. data).

The consistent observations of individuals returning to the same region each trip regardless of other animals' movements suggest a short- or long-term learned behavioural preference by female NZ sea lions. Further research is needed to test whether this is consistent for individuals across seasons, which would strengthen this assumption. In addition, a study on the foraging trip location patterns of lactating females from Dundas Island $(8 \mathrm{~km}$ southeast of Enderby Island; Fig. 1), NZ sea lions' largest breeding colony (ca. 1500 breeding females), is warranted to increase our understanding of where all lactating NZ sea lions from the northern Auckland Island colonies forage and allow a comparison of locations of foraging females between breeding colonies. Determining whether this occurs is important for the management of the species, and the management of the sub-Antarctic squid fisheries. If different colonies show different foraging locations, colonies would be able to be modelled separately, 
taking into account different prey availability and fishing pressure.

Overall, these results have important consequences for current management for the NZ sea lion population. First, the variation in the foraging ranges of females indicates that only a large protected area would cover all or even the majority of the female NZ sea lion foraging range. However, there are areas where fishing restrictions could be extended such as the area to the northwest of Enderby Island that could significantly decrease the sea lion bycatch numbers. Second, the known temporal and spatial overlaps in female foraging locations and fishing operations indicate the high potential for ecological as well as operational resource competition and may be a significant factor in controlling the static sea lion numbers and viability.

Acknowledgements. This work was conducted under a permit from the New Zealand Department of Conservation (DOC), and was funded by DOC, Science and Research Unit (Investigation no. 1638), Canterbury University, and by the Conservation Services Levy from the New Zealand Squid Fishery Management Company. DOC Southland are thanked for their logistical assistance. We also thank J. Amey, A. Castinel, S. Childerhouse, W. Hockley, F. Jonker, A. Maloney, P. McClelland, F. Riet Sapriza, M. Stratton and M. Wylie for assistance with captures in the field. Thanks also to B. Robertson for help with the graphics. Approval for work was obtained from DOC Animal Ethics Committee - Approval AEC86 (1 July 1999). B. Robertson, I. West and 2 anonymous reviewers all provided helpful, critical reviews of the manuscript. This research was conducted while B.L.C. held a Foundation for Research, Science and Technology Fellowship contract \# UOCX0105. We thank the Research Data Management section of the Ministry of Fisheries, New Zealand, for the arrow squid fisheries operational locations data and sea lion bycatch data.

\section{LITERATURE CITED}

Arnould JPY, Hindell MA (2001) Dive, behaviour, foraging locations, and maternal-attendance patterns of Australian fur seals (Arctocephalus pusillus doriferus). Can J Zool 79: 35-48

Baird SJ (1996) Non fish species and fisheries interactions working groups report. May 1996. New Zealand Fisheries Assessment Working Group Report 96/1, Ministry of Fisheries, Wellington

Bonadonna F, Lea MA, Guinet C (2000) Foraging routes of Antarctic fur seals (Arctocephalus gazella) investigated by the concurrent use of satellite tracking and time depth recorders. Polar Biol 23:149-159

Boyd IL (1999) Foraging and provisioning in Antarctic fur seals: inter-annual variability in time-energy budgets. Behav Ecol 10:198-208

Boyd IL, Arnould JPY, Barton T, Croxall JP (1994) Foraging behaviour of Antarctic fur seals during periods of contrasting prey abundance. J Anim Ecol 63: 703-713

Boyd IL, McCafferty DJ, Walker TR (1997) Variation in foraging effort by lactating Antarctic fur seals: response to simulated increased foraging costs. Behav Ecol Sociobiol 4: 135-144
Boyd IL, McCafferty DJ, Reid K, Taylor R, Walker TR (1998) Dispersal of male and female Antarctic fur seals (Arctocephalus gazella). Can J Fish Aquat Sci 55:845-852

Boyd IL, Staniland IJ, Martin AR (2002) Distribution of foraging by female Antarctic fur seals. Mar Ecol Prog Ser 242: 285-294

Campagna C, Werner R, Karesh W, Marin MR, Koontz F, Cook R, Koontz C (2001) Movements and location at sea of South American sea lions (Otaria flavescens). J Zool (Lond) 257:205-220

Cawthorn MW, Crawley MC, Mattlin RH, Wilson GJ (1985) Research on pinnipeds in New Zealand. Wildlife Research Liaison Group Report No. 7, Wellington

Childerhouse S, Dix B, Gales NJ (2001) Diet of New Zealand sea lions (Phocarctos hookeri) at the Auckland Islands. Wildlife Res 28:291-298

Costa DP, Gales NJ (2000) Foraging energetic and diving behaviour of lactating New Zealand sea lions, Phocarctos hookeri. J Exp Biol 203:3655-3665

Costa DP, Gales NJ, Crocker DE (1998) Blood volume and diving ability of the New Zealand sea lions, Phocarctos hookeri. Physiol Zool 71:208-213

Costa DP, Gales NJ, Goebel ME (2001) Aerobic dive limit: How often does it occur in nature? Comp Biochem Physiol Ser A 129:771-783

Crocker DE, Gales NJ, Costa DP (2001) Swimming speed and foraging strategies of New Zealand sea lions (Phocarctos hookeri). J Zool (Lond) 254:267-277

Doonan IJ, Cawthorn MW (1984) Impacts of incidental mortality on the Hookers sea lions. Internal Report No. 6, Fisheries Research Division, New Zealand Ministry of Fisheries, Wellington

Duignan PJ (1999) Gross pathology, histopathology, virology, serology and parasitology. In: Baker A (ed) Unusual mortality of the New Zealand sea lion, Phocarctos hookeri, Auckland Islands, January-February 1998: a report of a workshop held 8-9 June 1998, Wellington, and a contingency plan for future events. Department of Conservation, Te Papa Atawhai, Wellington, p 29-33

Gales NJ (1995) New Zealand (Hooker's) sea lion recovery plan. Threatened species recovery plan series 17 . Department of Conservation, Wellington

Gales NJ, Costa DP (1997) The Australian sea lion: a review of an unusual life history. In: Hindell M, Kemper C (eds) Marine mammal research in the southern hemisphere. 1: Status, ecology and medicine. Surrey Beatty, Chipping Norton, p 78-87

Gales NJ, Fletcher DJ (1999) Abundance, distribution and status of the New Zealand sea lion, Phocarctos hookeri. Wildlife Res 26:35-52

Gales NJ, Mattlin RH (1997) Summer diving behaviour of lactating New Zealand sea lions, Phocarctos hookeri. Can J Zool 75:1695-1706

Gales NJ, Mattlin RH (1998) Fast, safe, field-portable gas anesthesia for pinnipeds. Mar Mamm Sci 14:355-361

Georges JY, Bonadonna F, Guinet C (2000) Foraging habitat and diving activity of lactating sub-Antarctic fur seals in relation to sea surface temperature at Amsterdam Island. Mar Ecol Prog Ser 196:291-304

Guinet C, Dubroca L, Lea MA, Goldsworthy S, Cherel Y, Duhamel G, Bonadonna F, Donnay JP (2001) Spatial distribution of foraging in female Antarctic fur seals Arctocephalus gazella in relation to oceanographic variables: a scale-dependent approach using geographic information systems. Mar Ecol Prog Ser 219:251-264

Harcourt RG, Schulman AM, Davis LS, Trillmich F (1995) Summer foraging by lactating female New Zealand fur 
seals (Arctocephalus forsteri) off Otago peninsular, New Zealand. Can J Zool 73:678-690

Harcourt RG, Bradshaw CJ, Dickson K, Davis L (2002) Foraging ecology of a generalist predator, the female New Zealand fur seal. Mar Ecol Prog Ser 227:11-24

Hitchmough RA (2002) New Zealand threat classification systems list 2002. Department of Conservation. Threatened Species Occasional Publication 23, Wellington

Hooge PN, Eichenlaub WM, Solomon EK (2000) Using GIS to analyse animals movements in the marine environment. Alaska Biological Science Centre. US Geological Survey, Gustavus, AK

Kirkman SP, Bester MN, Makhado AB, Pistorius PA (2003) Female attendance behaviour of Antarctic fur seals at Marion Island. Afr Zool 38:402-405

McCafferty DJ, Boyd IL, Walker TR, Taylor RI (1998) Foraging responses of Antarctic fur seals to changes in the marine environment. Mar Ecol Prog Ser 166:285-299

Ponganis PJ, Ponganis EP, Ponganis KV, Kooyman GL, Gentry RL, Trillmich F (1990) Swim velocities in otariids. Can J Zool 68:2105-2112

Reijnders $\mathrm{P}$, Brasseur S, van der Toorn J, van der Wolf $\mathrm{P}$, Boyd I, Harwood J, Lavigne D, Lowry L (1993) Seals, fur seals, sea lions and walrus, status survey and conservation plan. IUCN/SSC Seal Specialist Group. International Union for Conservation of Nature and Natural Resources, Gland

Schulz TM, Bowen WD (2004) Pinniped lactation strategies: evaluation of data on maternal and offspring life history traits. Mar Mamm Sci 20:86-114

Seaman DE, Powell RA (1996) An evaluation of the accuracy

Editorial responsibility: Otto Kinne (Editor-in-Chief),

Oldendorf/Luhe, Germany of kernel density estimators for home range analysis. Ecology 77:2075-2085

Staniland IJ, Boyd IL (2003) Variation in the foraging location of Antarctic fur seals (Arctocephalus gazella), the effects on diving behaviour. Mar Mamm Sci 19:331-343

Staniland IJ, Reid K, Boyd IL (2004) Comparing individual and spatial influences on foraging behaviour in Antarctic fur seals, Arctocephalus gazella. Mar Ecol Prog Ser 275: 263-274

Sutherland WJ (1997) From individual behaviour to population ecology. Oxford University Press, Oxford

Taylor RH (1971) Influence of man on vegetation and wildlife of Enderby and Rose Islands, Auckland Islands. NZ J Bot 9:225-268

Thompson D, Duck CD, McConnell BJ, Garrett J (1998) Foraging behaviour and diet of lactating female southern sea lions (Otaria flavescens) in the Falkland Islands. J Zool (Lond) 246:1975-1982

Uozumi Y (1998) Fishery biology of arrow squids, Nototodarus gouldi, and N. sloanii, in New Zealand waters. Bull Natl Res Inst Far Seas Fish 35:1-111

Wilkinson IS, Burgess J, Cawthorn MW (2003) New Zealand sea lions and squid-managing fisheries impacts on a threatened marine mammal. In: Gales N, Hindell M, Kirkwood R (eds) Marine mammals: fisheries, tourism and management issues. CSIRO Publishing, Melbourne, p 192-207

Woodley TH, Lavigne DM (1993) Potential effects of incidental mortalities on the Hooker's sea lions (Phocarctos hookeri) population. Aquat Conserv 3:139-148

Worton BJ (1989) Kernel methods for estimating the utilization distribution in home-range studies. Ecology 70:164-168

Submitted: December 3, 2004; Accepted: March 22, 2005

Proofs received from author(s): November 23, 2005 